\title{
Crinoid stalk flexibility: theoretical predictions and fossil stalk postures
}

TOMASZ K. BAUMILLER AND WILLIAM I. AUSICH

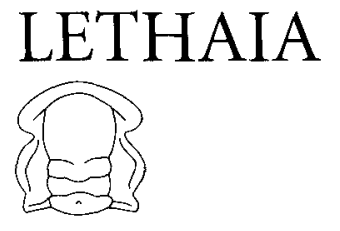

Crinoid stalks are morphologically diverse. Columnals have a variety of sizes, shapes, facet topographies, lumen sizes, and lumen shapes (Moore et al. 1968); and columnals form stalks of differing lengths. Intuitively, this rich morphological diversity should have a functional basis, but relatively little work has been completed on the relationship between columnal form and function (see Riddle et al. 1988; Donovan 1988, 1989, 1990; Guensburg 1992). Part of the problem lies in identifying the precise function that stalks fulfill. A relatively non-controversial, albeit limited, interpretation of stalk function is that the stalk (1) anchors the animal to the substratum, (2) elevates the crown above the substratum, and (3) allows the crown to be oriented into an effective feeding posture. Although a tether function has been previously suggested (Breimer \& Webster 1975), in extant crinoids the stalk is undoubtedly a rigid support (Baumiller 1992) rather than a tether.

The fulfillment of functions (2) and (3) implies that stalk flexibility is important. In extant crinoids, the stalk above the holdfast is positioned more-or-less vertically with the proximal portion bent at nearly a right angle orienting the crown perpendicular to the current in a feeding posture. Given the ecological importance of flexibility, it would be interesting to know which, if any, morphological characters of the stalk affect flexibility. Although flex- ibility differences have been inferred for fossil stalks, no general rules for factors controlling flexibility have emerged. In fact, certain characters have been interpreted both to increase flexibility and to increase stiffness. For example, column flexibility is generally inferred to have been enhanced by shorter columnals (Guensburg 1992; Stukalina 1988), but in the proxistele shorter columnals allowed only slight flexure (Ausich 1977; Guensburg 1992). Either one of these interpretations is incorrect or some factor other than columnal height controlled flexibility.

Our goal in this study is two-fold. First, we will examine stalk flexibility as a function of character variability by modelling the stalk as a modified cantilever beam. This purely mechanical model allows for independent assessment of various morphological characters on stalk bending. Second, the predictions of the theoretical model will be tested with fossil data from preserved postures of complete and nearly complete crinoid stalks from the Lower Mississippian crinoid beds at Crawfordsville, Indiana (Van Sant \& Lane 1964; Lane 1973). This fauna contains many species from all major Mississippian clades, and numerous specimens are preserved with complete stalks. The full spectrum of Lower Mississippian epifaunal suspension-feeding tiers was occupied in this fauna (Ausich 
1980), and conventional columnal facets (symplectial) as well as highly modified facets are represented.

Besides examining variables that control flexibility, we demonstrate the importance of ligaments and the likelihood that ligaments in Mississippian crinoid stems behaved like the mutable ligament of living crinoids. Flexibility in xenomorphic columns is also examined. Before discussing results, a brief survey of stalk morphology is given. Specific methods are discussed for each section independently.

\section{Morphology}

Crinoid stalk and columnal morphology were detailed by Moore et al. (1968) and Ubaghs (1978), but a brief discussion of certain common morphologic characteristics is a necessary introduction. In spite of great morphological variability, the overwhelming majority of crinoid columnals are discs of calcite wider than high. Columnals are stacked to form a stalk that is rigidly (either temporarily or permanently) attached distally to a substratum and proximally to a calyx. Individual columnals are pierced by the lumen, a central hole through which extensions of the chambered organ and nervous system penetrate the stalk.

Adjacent columnals are joined by ligamentary connective tissue. No muscular tissue is known in the stalk of any living crinoid (Grimmer et al. 1984a, b, 1985), and no evidence exists for muscles in stalks of any fossil crinoids (Donovan 1989). However, crinoid ligaments (Wilkie et al. 1993) composed of mutable collagenous tissues (MCTs) are marvelously versatile, as in all echinoderms. They cannot contract actively, but their tensile properties can be varied virtually instantaneously (Wilkie \& Emson 1988). Additionally, the 'catch' properties allow an individual to hold a position for long periods of time, probably without expending energy.

Mechanically, movement between two columnals occurs typically as a $3^{\circ}$ lever, i.e. the fulcrum lies on the peripheral, outer margin of a columnal. Exceptions inclide radical morphological modifications, such as a synarthrial articulation with a central fulcral ridge (see Platycrinites and Camptocrinus discussed below) or the central 'boss' of Gilbertsocrinus (Riddle et al. 1988, and discussion below).

\section{Methods and materials}

Stalk architecture and flexibility are evaluated principally using specimens from a single crinoid locality, the Lower Mississippian Lagerstätte at Crawfordsville, Indiana. A few additional specimens were also measured from the slightly younger site at Indian Creek, Indiana. With specimens principally from a single site, variables such as dep-

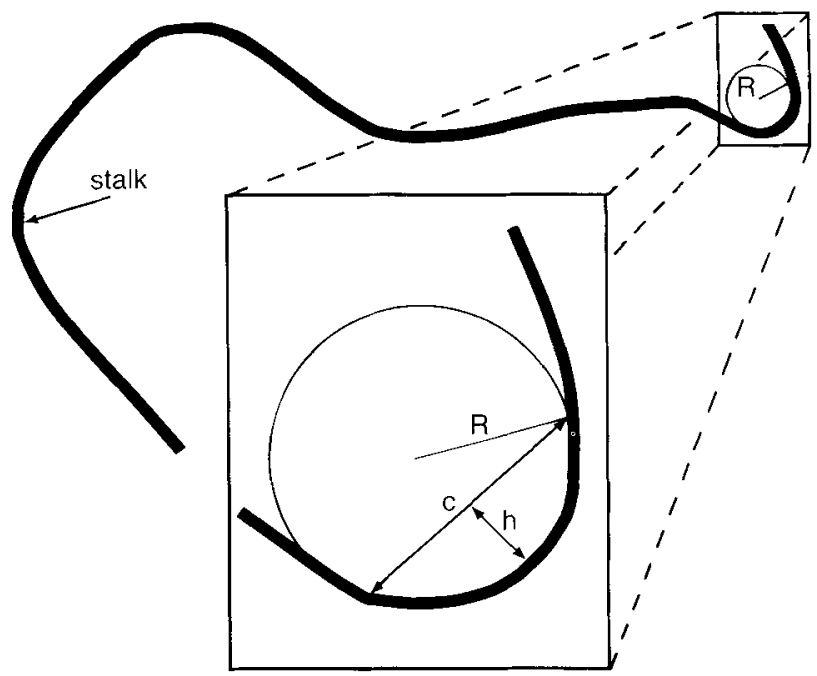

Fig. 1. Variables for calculating maximum observed flexibility (MOF) The radius of curvature was calculated for the most curved portion of the most curved stalk for each species. The radius of curvature ( $R$ ) is calculated using Equation 1, where $c$ is a chord for the arc of curvature, and $h$ is the segment that is perpendicular to and bisecting $c$.

ositional rate and environmental turbulence, which could add noise to the data, are minimized. All measured specimens have a substantial amount of column attached, and most have complete or nearly complete stalks (by a 'nearly complete' stalk, we imply one terminates within the holdfast region but does not show the complete holdfast).

Both sites are from the Lower Mississippian (upper Osagean) Edwardsville Formation (Van Sant \& Lane 1964; Lane 1973; Ausich \& Kammer 1991), deposited as part of platform sediments of the Borden deltaic complex (Ausich et al. 1979). Crawfordsville crinoids are preserved in siltstones, and Indian Creek crinoids tend to be preserved in limestones interbedded with siltstones.

These Lower Mississippian crinoids are ideal for this study, because relative to most other crinoid occurrences, numerous specimens are preserved with the column attached, and data can be collected from crinoids representing six clades (Table 1).

Stalks of 129 individuals assigned to 33 species were measured (Table 1). Two metrics of stalk flexibility were used: Maximum Observed Flexibility (MOF) and Realized Flexibility (RF). MOF is simply the radius of curvature for the most highly curved portion of the stalk. MOF was obtained by (1) identifying 'by eye' the most flexed column section for a species, (2) determining the end points of the arc thus identified, (3) constructing and measuring the chord for the arc ( $c$ in Fig. 1), and (4) measuring the segment ( $h$ in Fig. 1) that is perpendicular to and bisects chord $c$. Using $c$ and $h$ the radius of curvature (R) was calculated using the expression: 
Table 1. Crinoids cvaluated for stem flexibility and posture, listed according to major clades. Primitive cladids, as used here are cyathocrines and dendrocrines sensu Moore \& Teichert (1978) or cladids lacking pinnules, whereas advanced cladids have pinnules and were the poteriocrines of Moore \& Teichert (1978). Two-letter abbreviations and total number of specimens for each species available for study are listed. All specimens are from the Department of Paleobiology, Smithsonian Institution; all specimens from Crawfordsville, Indiana, except $\left(^{*}\right)$ all measured specimens from Indian Creek, Indiana; (**) one of the measured specimens from Indian Creek, Indiana (see Lane 1973; Ausich \& Kammer 1991 ).

\begin{tabular}{|c|c|}
\hline Species & Specimens measured \\
\hline \multicolumn{2}{|l|}{ Diplobathrida } \\
\hline Gillertsocrinus tuberosus (GT) & 5 \\
\hline \multicolumn{2}{|l|}{ Monobathrida } \\
\hline Abatocrinus grandis ( $\mathrm{AG}$ ) & 2 \\
\hline Actinocrinites gibsoni $i^{\star}(\mathrm{BB})$ & 6 \\
\hline Agaricocrinus splendens* (AS) & 2 \\
\hline Camptocrinus plenicirrus (CU) & 1 \\
\hline Camptocrinus crawfordsvillensis $(\mathrm{CV})$ & 2 \\
\hline Camptocrinus myelodactylus** (CY) & - \\
\hline Dichocrinus ficus (DF) & 1 \\
\hline Dizygocrinus indianensis (DI) & 6 \\
\hline Dizygacrinus montgomeryensis (DM) & 1 \\
\hline Eretmocrinus granuliferous (EG) & 1 \\
\hline Macrocrinus mundulus* (MM) & 3 \\
\hline Parudichoctinus polydactylus (PP) & 4 \\
\hline Platycrinites hemisphaericus $(\mathrm{PH})$ & 14 \\
\hline Platycrinites saffordi ${ }^{*}$ (PS) & 1 \\
\hline \multicolumn{2}{|l|}{ Disparida } \\
\hline Eucatillocrinus bradleyi (EB) & 2 \\
\hline
\end{tabular}

\section{Primitive Cladida}

Barycrinus thombiferans** $(\mathrm{BC})$

Barycrinus stellatus (BT)

Cyathocrinites multibrachiatus (CM)

Cyathocrinites iowensis (CI)
Parisocrinus crawfordsvillensis (PC)

Advanced Cladidat

Abrotocrinus unicus $(A U)$

Cydrocrinus concinnus ${ }^{*}$ (CC)

Histocrinus coreyi $(\mathrm{HC})$

Hypselocrinus hoveyi $(\mathrm{HH})$

Lanecrimus depressus (LD)

Pachylocrinus aequalis (PA)

Pellecrinus hexadactylus (PX)

Scytalocrinus robustus (SR)

Flexibilia

Forbesiocrinus wortheni ${ }^{* *}(\mathrm{FW})$

Onychocrinus exsculptus (OE)

Onychocrinus ramulosus (OR)

Taxocrinus colletti (TC)

$$
\mathrm{R}=h /\left(2 \cos ^{2}\left(\tan ^{-1}(c / 2 h)\right)\right)
$$

The greater the value of $\mathrm{R}$ and MOF, the lower the curvature and the lower the inferred flexibility for that species.

The second flexibility metric, RF, is the ratio of the linear distance from the proximal to the distal portion of the entire stalk (A) to the stalk length (D) $(R F=A / D ; F i g .2)$.

\section{Measured parameters for flexibility}

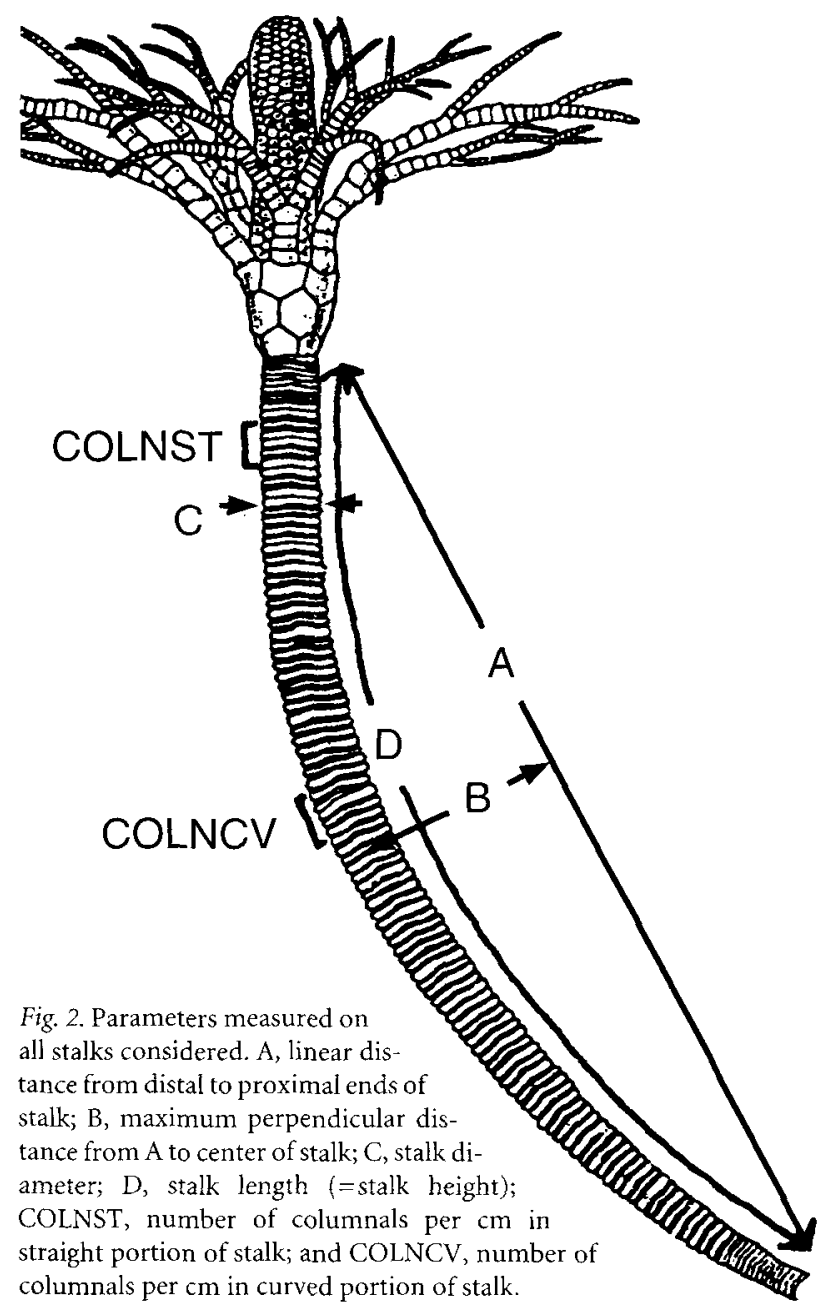

Higher flexibility is recorded by lower RF values, and as RF approaches 1 the stalk becomes straighter. For both metrics, MOF and RF, higher values indicate lower flexibility.

Additional measurements and counts on entire stalks include $\mathrm{B}$, maximum perpendicular distance from the line defined by $A$ to the center of the column; $C$, columnal diameter (Fig. 2); number of columnals per $1 \mathrm{~cm}$ in the portion of the column with maximum preserved curvature; number of columnals per $1 \mathrm{~cm}$ in a straight portion of the column; percentage of columnal facet diameter that is occupied by the lumen; and percentage of columnal facet diameter that is occupied by the crenularium. Columnal shape was classified as either circular, subpentagonal, or pentagonal.

Interpretations of stalk flexibility, both MOF and RF, rely on the assumption that the curvature of a preserved stalk was constrained by the flexibility of that stalk when 
it was alive. We regard this assumption to be straightforward, but the preserved curvature should be expected to record any posture from a straight, unflexed position to its maximum flexibility. Ideally, several specimens should be studied to approach maximum flexibility.

\section{Theoretical model: Stalk as a cantilever}

Cantilever beams are structures that are typically higher than wide, rigidly anchored at one end, free at the opposite end, and subjected to an external force somewhere along their length. A crinoid stalk fulfills these conditions. Whether or not the holdfast is permanently attached, the stalk is firmly anchored to the substratum. The crown is free and subjected to a set of forces. Drag on the crown by the current is the principal force bending the stalk, but minor gravitational and lift forces also exist (Baumiller 1992).

The amount of deflection $(\Delta)$ that the free end of a cantilever beam will experience owing to a point load is expressed by the following equation:

$\Delta=\mathrm{FL}^{3}(\mathrm{IE})^{-1}$

where $F$ is the force applied at the free end, $L$ is the length, $\mathrm{E}$ is the stiffness (Young's modulus), and I is the second moment of area. For a cantilever beam of circular crosssection (the cross-section of the majority of crinoid stalks), $\mathrm{I}$ is proportional to $\mathrm{R}^{4}$, where $\mathrm{R}$ is the beam radius.

Equation 2 describes a typical cantilever, i.e. one made of homogenous material; but a crinoid stalk is not homogenous along its length. A crinoid stalk is a beam of serially arranged rigid discs (columnals) connected by extensible ligament. When the stalk bends, it is the ligament fibers that undergo extension; the columnals retain their dimensions and behave inelastically. Therefore, stalk flexibility is controlled by total length (the sum length of all columnals) and by the length and position of the ligamentary tissues. Crinoid stalk construction implies that Equation 2 should be modified to include terms for columnal height, ligament length, and ligament distribution.

A modified version of Equation 2 was developed (Baumiller 1993) based on an algorithm suggested by Morgan \& Cannell (1987). In Baumiller's model the beam consists of a number of short segments; and the length, size, and stiffness of each segment is defined (Fig. 3). This model approximates a crinoid stalk if each segment represents a single columnal with appropriate dimensions and properties. Once the properties of each segment are defined, a set of equations describing the forces and moments at the segment's proximal and distal ends are derived. The equations for both ends of each segment are treated as simultaneous equations and solved using the transfer matrix method, by assigning an initial set of values at the base of

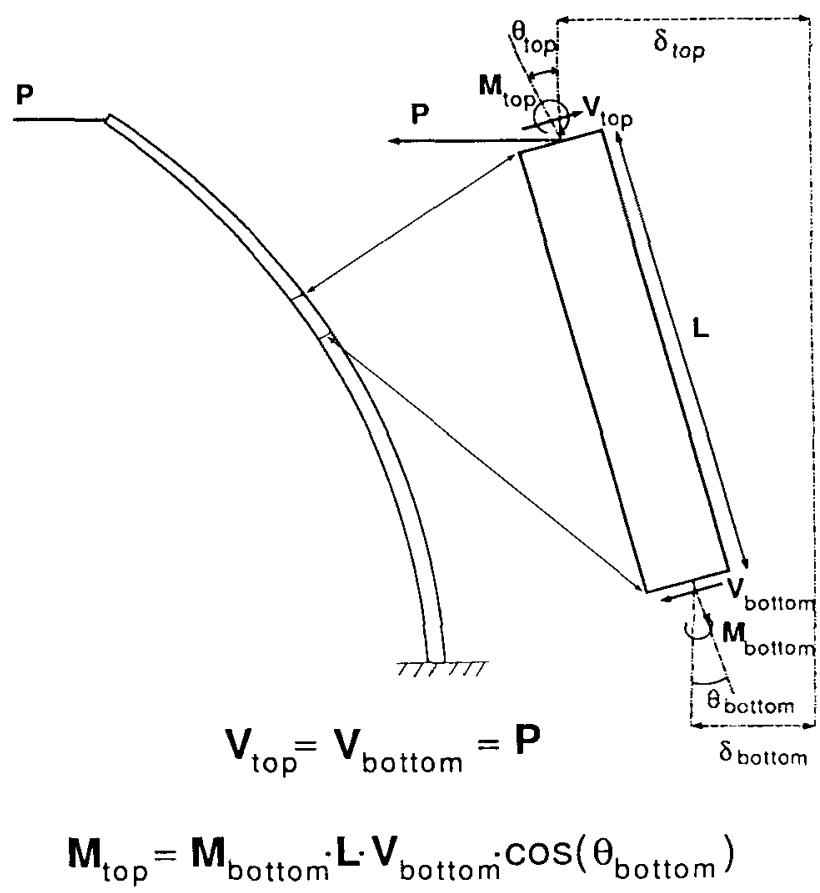

Fig. 3. Schematic drawing of the method for calculating the deflection in a crinoid stalk based on modification from Morgan \& Cannell (1987) (see Baumiller 1993). V are forces, and $\mathrm{M}$ are moments that are calculated sequentially for beam segments beginning with the bottom-most segment.

the stalk and proceeding toward the top. Because the boundary conditions at the attached end (deflection equals 0 ) and free end (bending moment equals 0 ) are known, the solution for the top of the beam can be calculated. If that solution produces a bending moment sufficiently close to 0 , it is accepted, otherwise the initial values are adjusted and the procedure is repeated. The process continues until close agreement is achieved between the solution and the boundary conditions. Using a PC, the correct answer can be obtained within minutes even for very complex beam morphologies.

\section{Cantilever model predictions}

Given this more complex cantilever beam model, we can assess the importance of single morphological characters on stalk flexibility by holding other variables constant. The characters examined include stalk diameter, stalk length, and columnal height. By varying each character and plotting solutions to the cantilever beam model, one can visually compare the character's effect on flexibility. Values of the two flexibility metrics developed above, MOF and RF, can also be computed for each modeled beam. These values are listed in Table 2 . 
Table 2. Measures of flexibility for modeled cantilevers. Calculations of $\mathrm{R}$ (and MOF) are based on an approximate fit of an arc, chord, and a perpendicular to the chord for each plotted solution.

\begin{tabular}{llll} 
Figure & Stalk (A/D) & RF (R) & MOF \\
\hline 4 & A & 0.99 & 210 \\
4 & B & 0.98 & 118 \\
4 & C & 0.96 & 56 \\
6 & A & 1.00 & 451 \\
6 & B & 1.00 & 256 \\
6 & C & 0.99 & 118 \\
8 & A & 0.96 & 65 \\
8 & B & 0.95 & 56 \\
8 & C & 0.95 & 59 \\
10 & A & 1.00 & 3597 \\
10 & B & 0.99 & 218 \\
10 & C & 0.97 & 95 \\
\hline
\end{tabular}

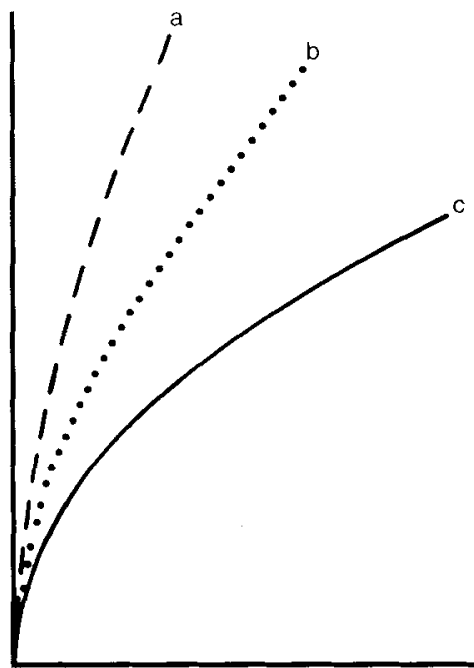

Fig. 4. Effect of stalk radius on stalk flexibility using the modified cantilever model. Curves A, B, and C represent deflection of stalks with different radii connected by long ligaments. Staik stiffness is a function of ligament stiffness and has a value of $1 \times 10^{9} \mathrm{~N} / \mathrm{m}^{2}$. The force applied at the free end of each stalk is $2 \mathrm{~N}$ and acts horizontally from left to right. Each stalk is 1 $\mathrm{m}$ long and is composed of 10 segments; each segment is $10 \mathrm{~cm}$ long. Stalk radii are $A, 0.75 \mathrm{~cm} ; \mathrm{B}, 0.63 \mathrm{~cm}$ and $C, 0.5 \mathrm{~cm}$.

\section{Stalk diameter}

As is evident from equation 2, the diameter of a beam should have a strong effect on flexibility. Solutions to the beam model confirm this (Fig. 4); the most slender beam exhibits the greatest deflection.

\section{Stalk length}

Using equation 2 , it is also easy to predict the effect of increasing beam length on flexibility: longer beams exhibit greater flexibility than shorter beams (Fig. 5A-B).

\section{Columnal height}

This trait is commonly considered as a control on flexibility by crinoid workers. In fact, the effect of columnal height depends on the distribution of the 'elastic' element (ligament) in the beam. If the elastic element is distrib-
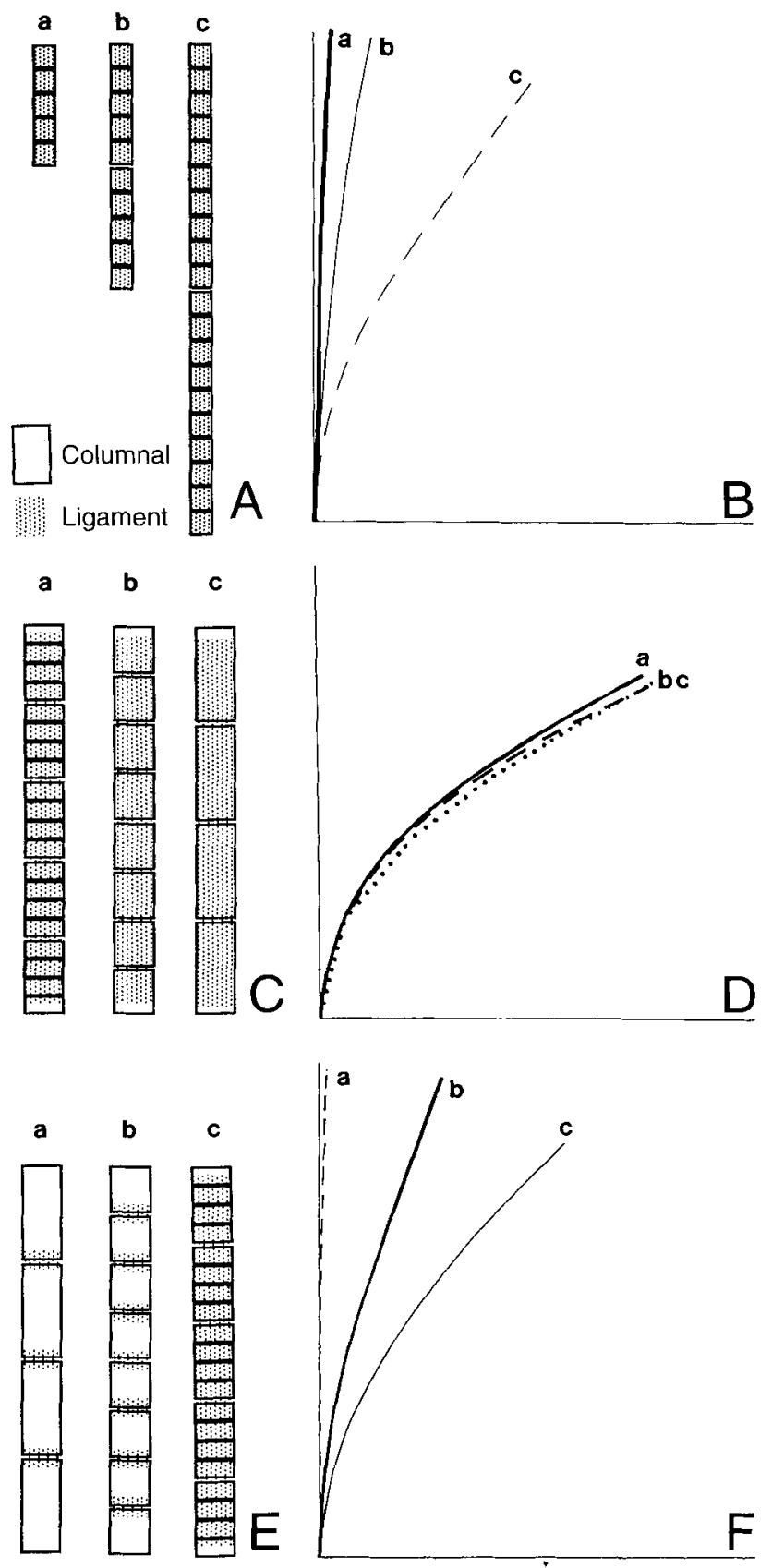

Fig. 5. Effects of various parameters on stalk flexibility using the modified cantilever model. In each case, as in Fig. 4 , stalk stiffness is a function of ligament stiffness and has a value of $1 \times 10^{9} \mathrm{~N} / \mathrm{m}^{2}$. The force applied at the free end of each stalk is $2 \mathrm{~N}$ and acts horizontally from left to right. Note that the cartoons in $\mathrm{A}, \mathrm{C}$, and $\mathrm{E}$ are only representative. $\square \mathrm{A}, \mathrm{B}$. Effect of stalk length on flexibility. Each stalk has columnals with a radius of $0.625 \mathrm{~cm}$ and columnal height of $5 \mathrm{~cm}$, but stalk length varies: $\mathrm{A}, 25$ cm ( 5 columnals); B, $50 \mathrm{~cm}$ ( 10 columnals); C, $100 \mathrm{~cm}$ ( 20 columnals). $\square C, D$. Effect of stalk flexibility in stalks with long ligaments and varying columnal height. Each stalk has columnals with a radius of $0.5 \mathrm{~cm}$ and stalk length of $1 \mathrm{~m}$, but columnal height varies: A, $2 \mathrm{~cm}$ ( 50 columnals) $\mathrm{B}, 5 \mathrm{~cm}$ ( 20 columnals); $\mathrm{C}, 10 \mathrm{~cm}$ (10 columnals). Note that no change in flexibility results. $\square$ E, F. Effect of stalk flexibility in stalks with short ligaments and varying columnal height. Each stalk has columnals with a radius of $0.5 \mathrm{~cm}$ and stalk length of $1 \mathrm{~m}$, but columnal height varies: $A$ $10 \mathrm{~cm}$ ( 10 columnals); B, $5 \mathrm{~cm}$ ( 20 columnals); C, $2 \mathrm{~cm}$ ( 50 columnals). Note that flexibility is affected by columnal height in stalks if ligaments are short. 
uted along the entire length of the beam, columnal height has no effect on flexibility. Deflections of stalks of equal lengths, one composed of many low columnals, another of few high columnals, and a third of intermediate height columnals, are equivalent (Fig. 5C-D).

On the other hand, if the elastic element is short, holds columnals together but extends only partially into them, and has a constant length independent of columnal height, columnal height will affect flexibility (Fig. 5E-F). To demonstrate this, consider two stalks of equal length, one with many thin columnals and the other with fewer, thicker columnals. Total ligament length in each stalk is proportional to the number of columnal articulations, i.e. to $n-1$, where $n$ is the number of columnals. In a stalk with shorter columnals, there is more ligament per unit stalk length, and a given stress will result in more extension of the ligament (though the same strain). Such a stalk is thus expected to be more flexible (Fig. $5 \mathrm{~F}$ ).

\section{Tests of theoretical model using fossil data}

Our model of the stalk as a cantilever beam allows us to make several predictions about skeletal architecture and flexibility. Stalk length and radius are important, columnal height may or may not be important depending on the distribution of soft tissues, and ligament stiffness (E) should be important. These predictions could be tested by examining the behavior of living crinoids in response to known forces; but because these animals are very difficult to observe and manipulate in situ, this approach is presently impractical. Instead, the model's predictions are tested with fossil stalks. This strategy presents numerous problems, such as the lack of data on properties or distribution of ligament, but it also has several distinct advantages. For example, remains of crinoid stalks rank among the most abundant Paleozoic macrofossils and allow us to test a much broader range of stalk morphologies than are represented among extant crinoids.

Of course, flexibility of fossil stalks cannot be assessed directly, but a signature of flexibility is retained by complete fossil stalks. Multicolumnal remains of stalks represent animals that were buried before the ligament decayed. The amount of curvature in a fossil stalk represents (1) the stalk's inherent flexibility and (2) the conditions at burial. If the conditions at burial, especially the forces on the crown, were constant, flexibilities of stalks of different dimensions can be compared: more flexible stalks should have greater curvatures than less flexible stalks. We cannot precisely determine burial conditions; however, as discussed above, the effect of this variable can be minimized by examining specimens principally from a single locality. We therefore use the radius of curvature in the maximally bent portion of the stalk (MOF) as a measure of stalk flexibility (see Equation 1). Additionally, preserved curvature would be affected if the stalk grew into a coiled posture. This is a factor for a few crinoids with obligate posture, as discussed below, but in general this has no importance for the data reported.
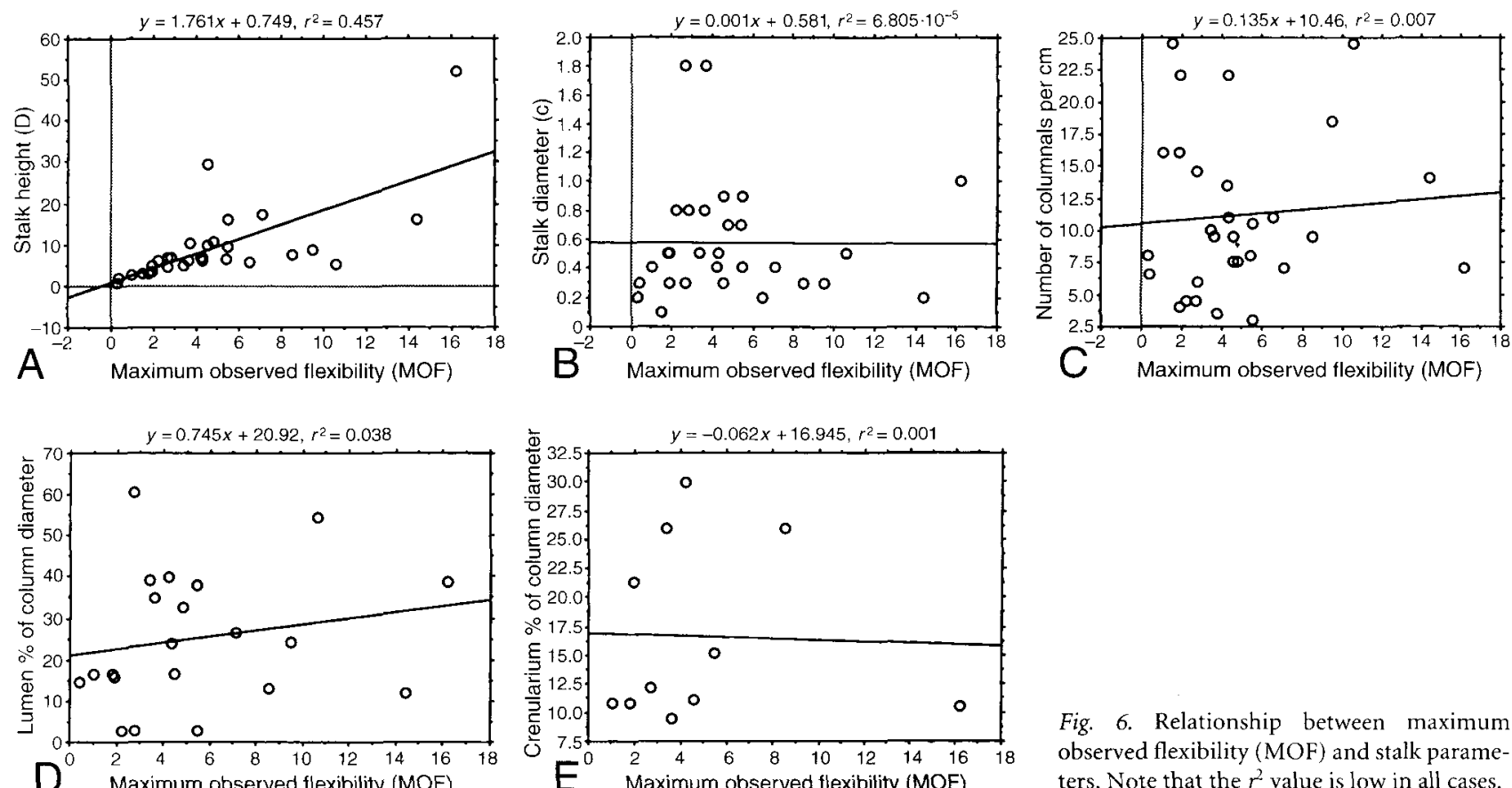

Fig. 6. Relationship between maximum observed flexibility (MOF) and stalk parameters. Note that the $r^{2}$ value is low in all cases. 

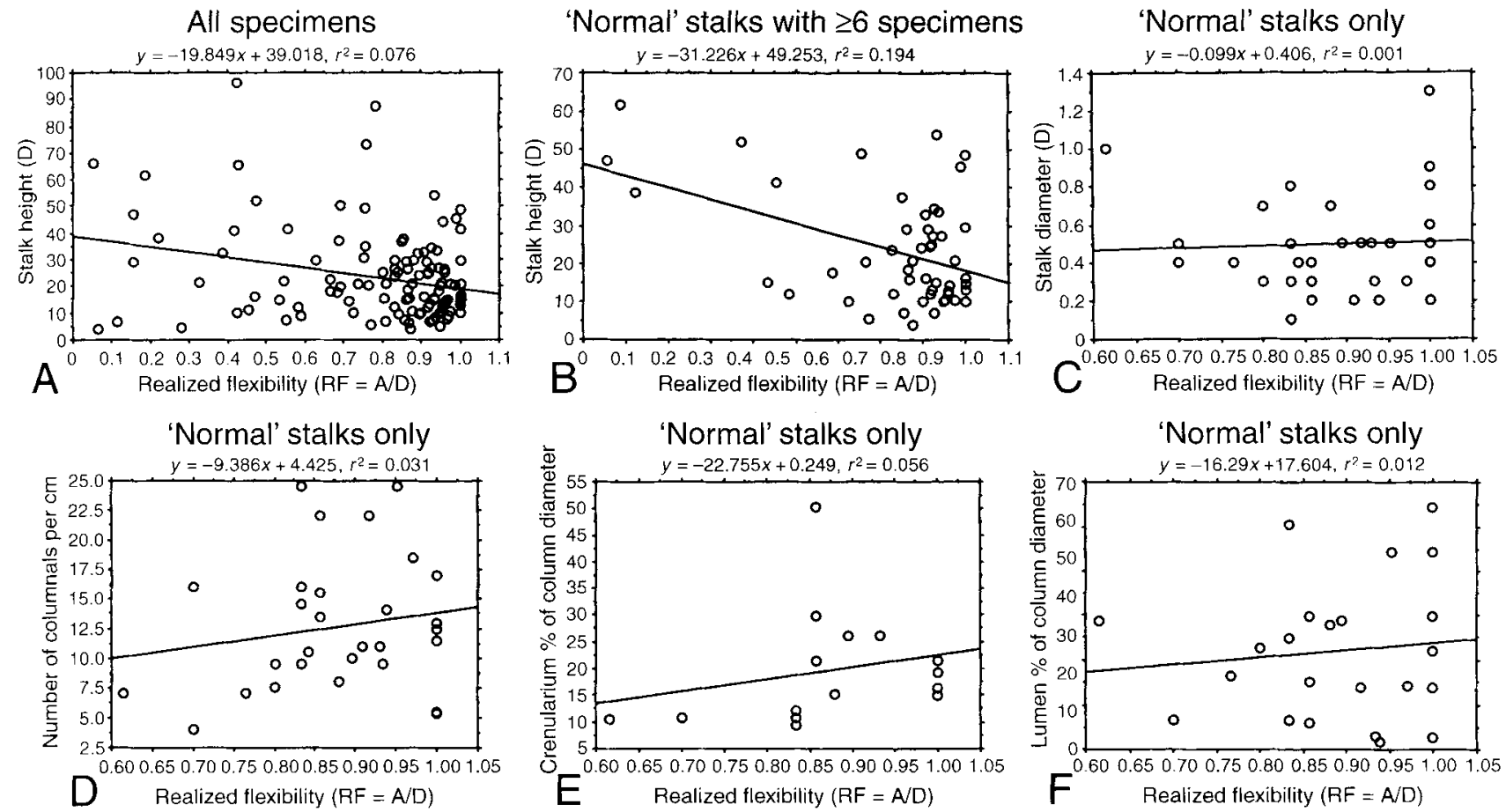

Fig. 7. Relationship between realized flexibility (RF) and stalk parameters. Note that the $r^{2}$ value is low in all cases. The three specimens with the lowest values of RF (Fig. 7B) are two Histocrinus coreyi and one Dizygocrinus indianensis (see Fig. 8).

\section{Results and interpretations}

The MOF is presented (Fig. 6) as a function of stalk diameter, stalk length, columnal height, percent crenularium, and percent lumen, but no significant relationship exists between flexibility and these characters. The strongest correlation is between MOF and D (Fig. 6A), but this only has an $\mathrm{r}^{2}$ value of 0.457 .

The lack of agreement between the predictions of the cantilever model and the observed postures implies that crinoid stalks do not behave like simple cantilevers and that some fundamental assumption of the model must be in error. The most obvious flaw in the model is the assumption that the ligament fibers, which control flexibility, had uniform and constant properties. This assumption may be questioned for two reasons: (1) ligament properties may be taxon-specific and, more importantly, (2) ligament properties may be actively controlled by the animal. Taxon-specific variability in ligament properties (Young's modulus) may account in part for the lack of correspondence between the data and the model's predictions, but the known variable properties of echinoderm ligament (MCT) are a more likely source of the discrepancy. Experimental studies of isocrinid ligament (Wilkie et al. 1993) and observations of isocrinids in situ and in the lab (Baumiller 1993) have shown that these animals can actively and rapidly modify the properties of ligament, changing the stalk from stiff (the ligament in the 'catch' state) to highly flexible (ligament out of 'catch'). Such variability in ligament stiffness may be of sufficient magnitude to negate the effects of skeletal architecture on stalk flexibility predicted by the cantilever beam model.

\section{Beyond the average stalk}

As demonstrated above, general features of columnal and stalk morphology are not good predictors of maximum observed flexibility (MOF), which implies that either the variable MCT properties, other morphological features, or both of these controlled flexibility of the stalk. If the flexibility metric for the entire stalk (RF) is considered, do any morphological characters emerge as relevant?

First, as with MOF, there are no significant correlations between RF and morphology (i.e. columnal height, columnal width, crenularium width, or lumen width) if all data are considered (Fig. 7A). RF varies along a spectrum from straight to quite curved (Fig. 8). Despite a lack of robust patterns in these data, certain species display a wider range of preserved postures and a wider range of flexibilities (e.g., Cyathocrinites iowensis, Histocrinus coreyi, and Taxocrinus colletti) than do others (Camptocrinus species are exclusively coiled; and Abatocrinus grandis, Actinocrinites gibsoni, Barycrinus rhombiferans, Hypselocrinus hoveyi, Pachylocrinus aequalis, Paradichocrinus polydactylus, and Scytalocrinus robustus are always pre- 
Fig. 8. Spectrum of realized flexibility (RF) per species for all specimens measured. Each square represents a single specimen with the corresponding RF value; a number is indicated where more than one specimen had identical $R F$ value. See Table 1 for species abbreviations.

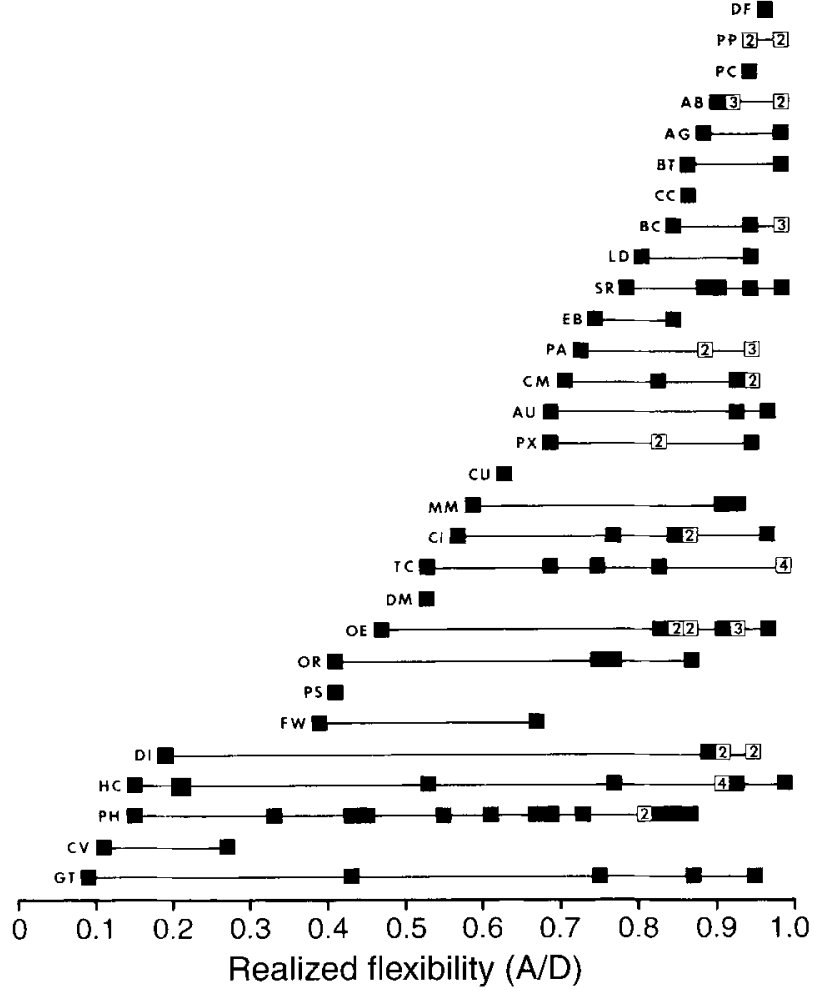

served straight or nearly straight) (Fig. 8). What causes these differences? Do morphological characters other than those examined above control flexibility?

Among Crawfordsville crinoids, taxa exhibiting unusual flexibility utilized a variety of strategies: (1) intercalation of wedge-shaped columnals, making curvature obligate; (2) increasing the length of the stalk; and (3) morphological modifications away from the typical stalk (circular to pentagonal, peripheral crenularium). We examine these and the functional morphology of the proxistele below.

\section{Obligate curvature}

A permanent solution to stalk curvature was the development of wedge-shaped columnals. This produced an obligate posture, presumably in a desirable orientation, but did so by limiting the ability to change posture. Both Cyathocrinites iowensis and C. multibrachiatus have wedge-shaped columnals immediately below the cup, giving the stalk a proximal kink (Fig. 9E). Maximum curvature in the proximal portion of the Camptocrinus crawfordsvillensis and Camptocrinus plenicirrus column was also accomplished, in part, with wedge-shaped columnals (contrary to Springer 1926, p. 26).

\section{Increased length}

Theoretically, flexibility of any stalk could be enhanced by increasing its length (D) (Fig. 5A, B). Fig. 7B shows the relationship among select crinoids with typical columnals (selected because they are known from six or more specimens and do not display obligate bending): stalk length and RF are not strongly correlated. However, for the two crinoids with exceptionally high flexibility (low RF value) and typical columnals (Histocrinus coreyi and Dizygocrinus indianensis), specimens with the greatest curvature have the longest stalks (Figs. 7B, 8). In fact, maximum curvature (minimum RF) occurs in specimens with the longest stalk for five of the eight species with typical stalks and a minimum RF of less than 0.6 (Fig. 8).

Even where stalk length appears to affect flexibility, it would be difficult to argue that greater length was an adaptation for increasing flexibility; the potential trophic value of increased stalk length (Ausich 1980; Bottjer \& Ausich 1986) may be more significant than any increases in flexibility.

\section{Reduced flexibility}

It would be interesting if stalks of particular species retained low flexibility despite being long. Why do the longest stalks of the crinoids selected in Fig. 8 have high flexibility, while no correlation exists between RF ( = A) D) and D? As mentioned above, Abatocrinus grandis (Fig. 9A), Actinocrinites gibsoni, Barycrinus rhombiferans, Hypselocrinus hoveyi, Pachylocrinus aequalis, Paradichocrinus polydactylus, and Scytalocrinus robustus generally have stalks with low curvature. Did these species have abnormally low flexibility, or were they simply never preserved in a posture that displayed maximum bending?

Various tendencies suggest that these stalks may have behaved differently. First, the seven crinoids clearly display smaller standard errors of RF values than other species considered (Table 3 ). Second, for the more flexed species there is a negative correlation between RF and length (Spearman rank correlation $=-0.397$ ), consistent with the theoretical prediction, whereas for the species with straighter stalks the correlation is, unexpectedly, positive (Spearman rank correlation $=+0.300$ ). Although neither is statistically significant, this suggests that these stalks were behaving differently from other typical columnals and that they may be straighter than expected. Because no morphological features can be attributed to these differences, it is possible that MCT distribution and/ or properties in these taxa were different from other species. However, because none of the relationships discussed are significant, we can only cautiously suggest that species-specific reduced flexibility may have been present in these seven crinoids. 

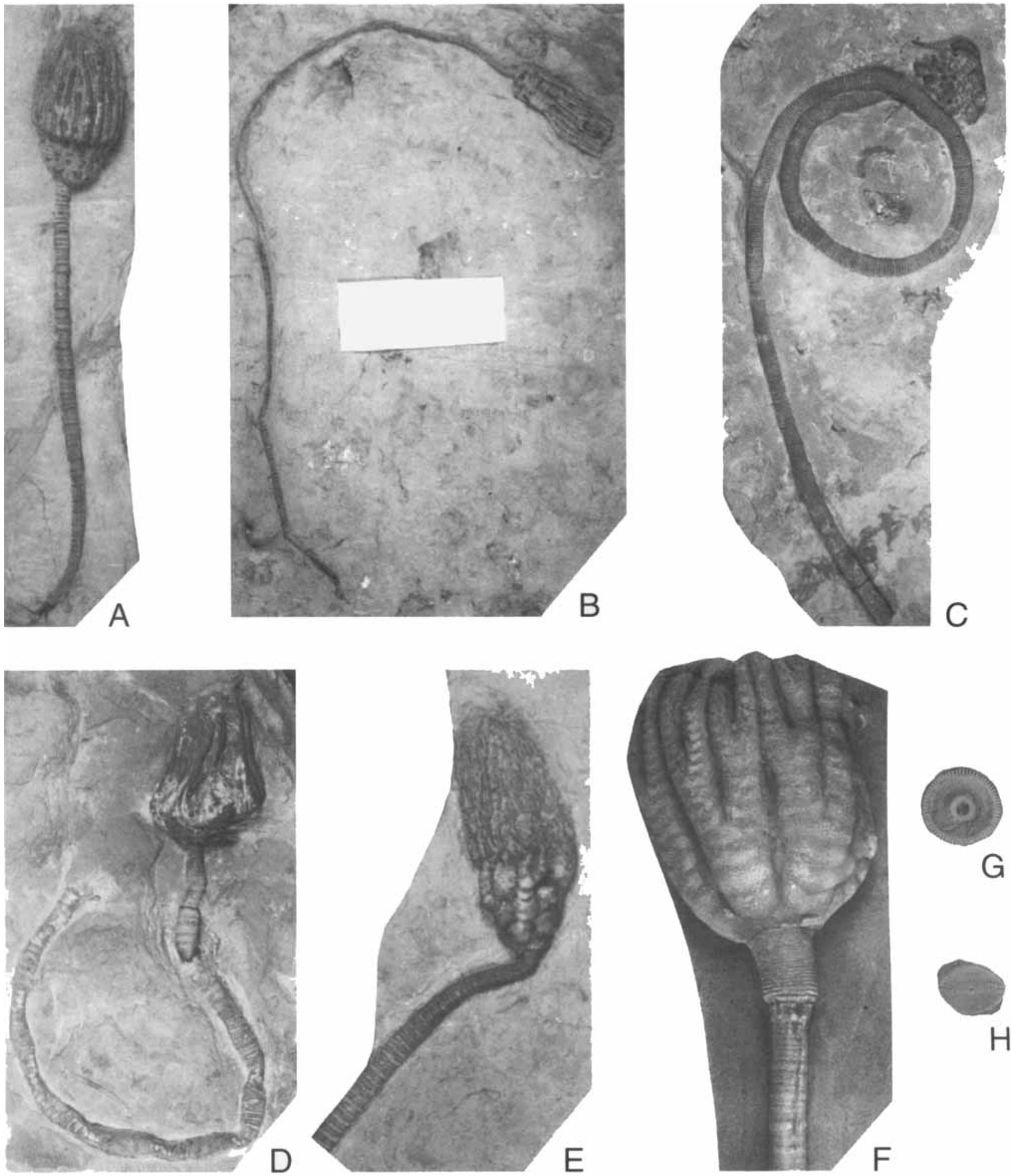

G

Fig. 9. Representative preserved stalk postures. $\square$ A. Abatocrinus grandis, this stalk is typically preserved straighter than expected, $\times 0.4$. $\square$ B. Abrotocrinus coreyi, $\times 0.3$. $\square$ C. Highly curved stalk of Gilbertsocrinus tuberosus, $\times 0.3 . \square \mathrm{D}$. Curved stalk typical of Platycrinites hemisphaericus, $\times 0.4$. $\square \mathrm{E}$. Cyathocrinites multibrachiatus; note the proximal kink in the stalk, which is the result of wedge-shaped columnals, $\times 0.75$. $\square$ F. Proximal stalk and crown of xenomorphic stalk of Taxocrinus colletti, note the very straight proxistele (immediately below the crown) even though it is composed of very short columnals, $\times 1.7 . \square$ G. Gilbertsocrinus tuberosus, articular facet. Note the crenularium on the narrow perilumen surrounding the lumen. This is the only area of articulation between adjacent columnals, $\times 1.4 . \square \mathrm{H}$. Platycrinites hemisphaericus, articular facet, note articular ridge across long diameter of facet, $\times 2.0$. 
Table 3. Comparison between crinoids with typical stalks (pentagonal to circular columnal shape and a peripheral crenularium) that appear to be straighter than expected versus those that display a wide range of preserved postures. Only those species with three or more specimens are included for the species with a wide range of postures. See Table 1 for abbreviations.

\begin{tabular}{llllr}
\hline \multirow{2}{*}{ Species } & \multicolumn{3}{l}{ RF Ratio } & \\
\cline { 2 - 5 } Straighter stalks & & & & \\
AB & & & & \\
AG & 0.950 & 0.001 & 0.035 & 6 \\
BC & 0.947 & 0.006 & 0.074 & 2 \\
HH & 0.963 & 0.004 & 0.060 & 5 \\
PA & 0.986 & 0.000 & 0.014 & 3 \\
PP & 0.899 & 0.008 & 0.089 & 6 \\
SR & 0.979 & 0.001 & 0.024 & 4 \\
More variable stalks & & & & 5 \\
II & 0.914 & 0.006 & 0.075 & \\
HC & 0.807 & 0.093 & 0.305 & 6 \\
MM & 0.725 & 0.097 & 0.312 & 3 \\
OE & 0.819 & 0.040 & 0.200 & 10 \\
OR & 0.861 & 0.019 & 0.137 & 4 \\
PX & 0.711 & 0.040 & 0.199 & 4 \\
TC & 0.831 & 0.012 & 0.109 & 8 \\
\hline ... & 0.854 & 0.031 & 0.175 & \\
\hline
\end{tabular}

\section{Non-obligate morphological modifications}

Three taxa stand out as having unusually high flexibility (low RF values): Platycrinites, Camptocrinus, and Gilbertsocrinus (Fig. 8). They achieved this high flexibility by radically modifying facet skeletal architecture, thereby changing the position of ligaments and the mechanics of the facets.

Elliptical columnals and synarthrial articulations were developed in Platycrinites and Camptocrinus. In Platycrinites each columnal is elliptical and normally has a well-developed synarthrial ridge coincident with the long axis of each facet (Ubaghs 1978; Riddle 1989). Synarthrial ridges on the proximal and distal facets are slightly offset on each columnal so that a complete stalk is helically twisted (Fig. 9D). Enhanced flexibility resulted from the changed mechanics of intercolumnar movement from a $3^{\circ}$ to a $1^{\circ}$ lever system. Ligaments were positioned perpendicular to and on opposite sides of the fulcrum. With the fulcrum along the center of the facet, maximum ligament stretching at the periphery of the facet could result in a greater amount of intercolumnar movement than in a similar-sized facet operating as a $3^{\circ}$ lever. Furthermore, in Platycrinites it is likely that ligaments were confined to the fossae occupying the central one-third of the facet (Fig. $10 \mathrm{E}$ ), further increasing flexibility. With bending mediated by the fulcral ridge, movement at each articulation was restricted to two directions. However, the entire stalk could bend in any direction because of its helically twisted morphology.

Several specimens of Platycrinites hemisphaericus were measured for this study, and they displayed a wide range of postures and realized flexibilities (Fig. 9D). RF values for $P$. hemisphaericus ranged from 0.155 to 0.881 (SD = $0.221, n=14$ ) (Fig. 8).

Camptocrinus had modifications similar to Platycrinites, in that most columnals were elliptical, and a synarthrial articulation was developed on facets. However, important differences existed. In Camptocrinus, articular ridges are aligned parallel on facets of a single columnal, resulting in a planispiral stalk coil (Fig. 10A, B), and the articular ridges lie either along the short or the long axis of the columnal depending on the position along the stalk. The stalk is xenomorphic, and coiling reverses in the proximal stalk yielding an S-shape. The stalk can be coiled around itself, and it is preserved in various degrees of curvature indicating that at least part of the opening and closing of coiling was mediated by intercolumnal flexure. In addition to a synarthrial articulation, the movement between adjacent columnals was enhanced by the inferred placement of ligaments. The stereomic microstructure of Camptocrinus columnals is partitioned into four distinct quadrants (Fig. 10A). Two types of microstructure are present: (1) a galleried stereom in the two quadrants aligned with the articular ridge ( $\mathrm{Fig} .10 \mathrm{C}$ ), and (2) a very open non-galleried stereom in the other two quadrants (perpendicular to the articular ridge) (Fig. 10D). If the galleried stereom housed ligaments (Macurda \& Meyer 1975), confinement of the ligaments proximal to the articular ridge would further enhance flexibility at each articulation (the same rationale applies for Platycrinites, as discussed above). The non-galleried stereom in these columnals has not been described previously. It is an orthogonal stereom with large rectangular pores and thin bars. The bars of each subjacent layer of stereom exactly bifurcate a superjacent stereom pore (Fig. 10D). Because this stereom has no modern analog, its interpretation is speculative. The open nature of the stereom may suggest that it was a 'filler' type of stereom and not associated with connective tissues responsible for intercolumnal movement.

The unusual nature of the Camptocrinus stalk has been recognized for a long time (Wachsmuth \& Springer 1897; Springer 1926); but its paleoecology is problematic. The proximal stalk of Camptocrinus has an S-curve, and thereafter it coils planispirally. It may coil around itself several times, and numerous cirri may obscure the crown within the stalk coil. A tight coil seems an unlikely life position. As recently interpreted by Maples \& Waters (1995), Camptocrinus was probably adapted to suspension feeding in low tiers. The greatly enhanced flexibility of this stalk allowed for the planispiral stem to coil either tightly or loosely. 

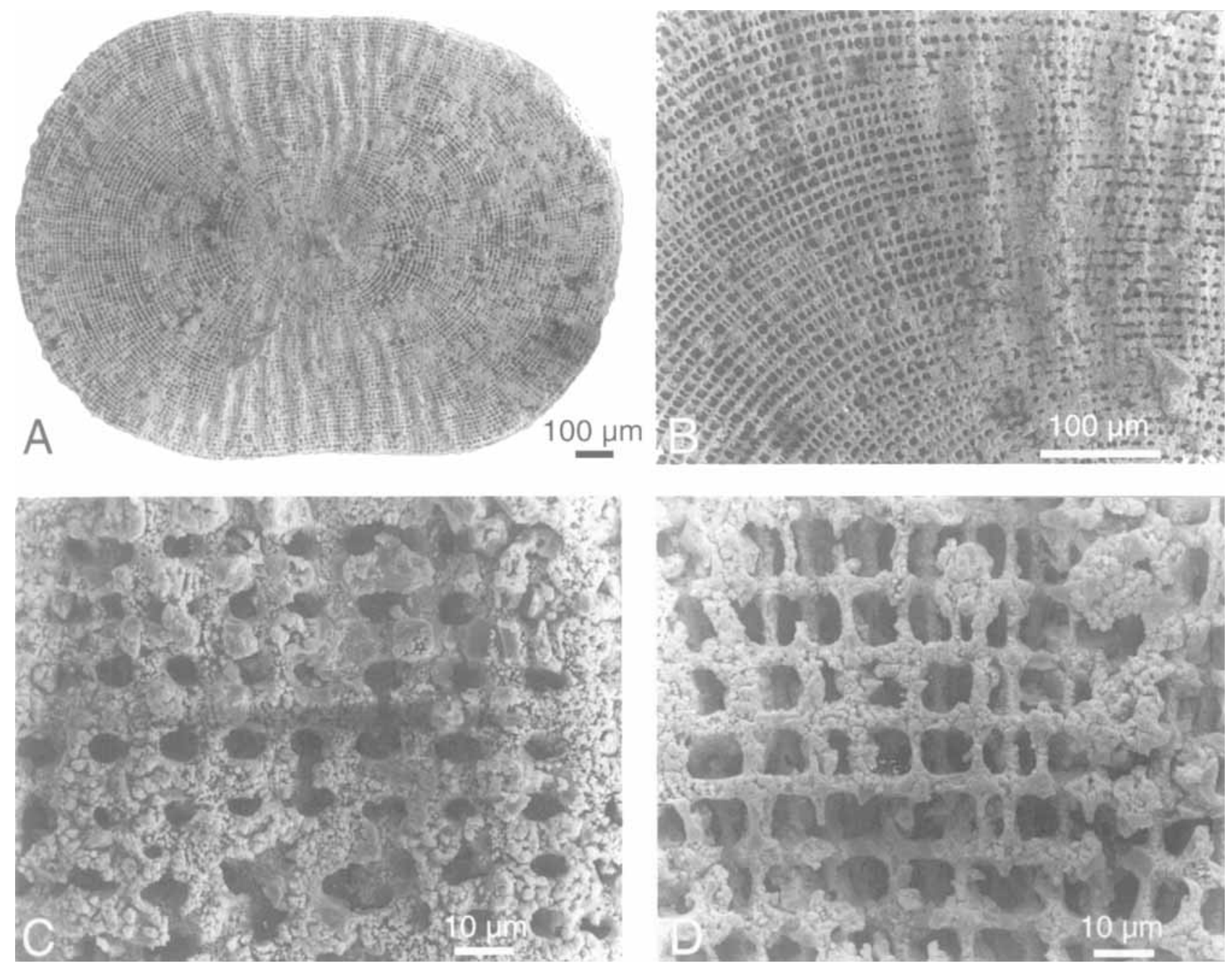

Fig. 10. SEM photomicrographs of Camptocrinus sp. columnar facets. $\square$ A. Entire facet; fulcrum represented by ridges across the narrow diameter, not discrete as in Platycrinites; scale bar $100 \mu \mathrm{m}$. $\square$ B. Enlargement of articular ridge; scale $100 \mu \mathrm{m}$. $\square$ C. Galleried stereom in region of articular ridge; scale $10 \mu \mathrm{m}$. $\square \mathrm{D}$. Unusual open, non-galleried stereom of regions away from the articular ridge, scale bar is $10 \mu \mathrm{m}$.

Gilbertsocrinus had the most flexible stalk among Crawfordsville crinoids with circular columnals. Gilbertsocrinus stalks are commonly preserved in one or more relatively tight coils (Lane 1963, 1973) (Fig. 9C). This high degree of flexibility has been interpreted by Riddle et al. (1988). The stalk is heteromorphic with nodals alternating with a single, much smaller internodal. In an unflexed column, the internodals are barely visible in lateral view. The crenularium, which houses through-going ligament, is not at the periphery of the columnal. Instead, it is confined to a relatively narrow perilumen immediately surrounding the lumen (Moore et al. 1968; Riddle et al. 1988) (Fig. 9G). In a straight posture adjacent columnals would only be in contact around this central perilumen. Although the leverage system of this facet design still operated as a $3^{\circ}$ lever, functionally it mimicked a $1^{\circ}$ lever or even a ball-and-socket type of joint (Riddle et al. 1988).
The result was a highly flexible and versatile column, and this is demonstrated by its preserved posture.

\section{Proxistele flexibility}

A superficially counter-intuitive interpretation of our results is that column flexibility is not inversely correlated with columnal height. The lack of a relationship may be due in part to differences in the distribution of ligaments among different taxa (Fig. 5) or to variable properties of the ligaments. Again, no a priori generalizations about flexibility and columnal height can be made, as both higher and lower flexibility may be associated with shorter columnals. For example, the proxistele, which is a stalk region composed of very short columnals, can be flexible, as in extant isocrinids, or stiff, as in the Crawfordsville crinoids. Of the 27 specimens of Crawfordsville crinoids 
with a well-defined proxistele (Eucatillocrinus bradleyi, Forbesiocrinus wortheni, Onychocrinus exsculptus, O. ramulosus, and Taxocrinus colletti), only three exhibited even a slight flexure in this region. Rather than being flexible, the proxistele among these taxa is interpreted as a very rigid portion of the stalk (Fig. 9F). This interpretation is consistent with observations on the Silurian disparid Pisocrinus (Ausich 1977), the Late Mississippian flexible Taxocrinus cf. T. whitfieldi (Wulff \& Ausich 1989), and Ordovician crinoids (Guensburg 1992).

\section{Conclusions}

1 The cantilever beam model predicts that stalk diameter, stalk length, and, under some circumstances, columnal height should affect stalk flexibility. Inferred flexibilities of Lower Mississippian stalks do not conform to these predictions, suggesting that flexibility is under the control of (a) some unrecognized skeletal features or (b) the ligaments. Because echinoderm ligament is composed of mutable collagenous tissue (MCT) with rapidly changeable properties, it is inferred that MCT was present in Lower Mississippian crinoid stalks and controlled stalk flexibility.

2 Among the Lower Mississippian crinoids studied, significant relationships do not exist between the inferred stalk flexibility and morphological features such as columnal height, columnal diameter, crenularium width, lumen width, or columnal shape. Skeletal morphology is generally not a good predictor of stalk flexibility.

3 Flexibility could be affected by radical changes of the morphology of columnal facets and articulation mechanics. For example, by moving the fulcrum articulation and the ligaments to a more central position, the resultant flexibility was increased. Platycrinites and Camptocrinus developed elliptical columnals and synarthrial articulations, and Gilbertsocrinus moved the crenularium onto a central perilumen.

4 Proxisteles composed of very short columnals in flexible and disparid crinoids are more rigid than the mesistele composed of taller columnals.

5 Wedge-shaped columnals provide an alternative, obligate means to change stalk posture.

Acknowledgments. - F.J. Collier and J.W. Thompson allowed access to Crawfordsville and Indian Creek crinoids at the U.S. National Museum of Natural History. H. Hayes typed the manuscript, and K. Tyler and B. Daye aided with the illustrations. This research was fully supported by the National Science Foundation (EAR-9104892). The author order of this paper was determined by coin toss.

\section{References}

Ausich, W.I. 1977: The functional morphology and evolution of Pisocrinus (Crinoidea: Silurian). Journal of Paleontology 51, 672-686.

Ausich, W.I. 1980: A model for niche differentiation in Lower Mississippian crinoid communities. Journal of Paleontology 54, 273-288.

Ausich, W.I. \& Kammer, T.W. 1991: Late Osagean and Meramecian Actinocrinites from the Mississippian stratotype region (Echinodermata: Crinoidea). Journal of Paleontology 65, 485-499.

Ausich, W.I., Kammer, T.W. \& Lane, N.G. 1979: Fossil communities of the Borden (Mississippian) delta in Indiana and northern Kentucky. Journal of Paleontology 53, 1182-1196.

Baumiller, T.K. 1992: Importance of hydrodynamic lift to crinoid autecology, or, could crinoids function as kites? Journal of Paleontology 66, 658-665.

Baumiller, T.K. 1993: Crinoid stalks as cantilever beams and the nature of stalk ligament. Neues Jahrbuch für Geologie and Paläontologie, Abhandlungen 190, 115-133.

Bottjer, D.J. \& Ausich, W.I. 1986: Phanerozoic development of tiering in soft substrata suspension-feeding communities. Paleobiology 12,400420 .

Breimer, A. \& Webster, G.D. 1975: A further contribution to the paleoecology of fossil stalked crinoids. Koninklijke Nederlandse Akademie van Wetenschappen Proceedings series B 78, 149-167.

Donovan, S.K. 1988: Functional morphology of synarthrial articulations in the crinoid stem. Lethaia 21, 69-175.

Donovan, S.K. 1989: The improbability of a muscular crinoid stalk. Lethaia 22,307-315.

Donovan, S.K. 1990: Functional morphology of synostosial articulations in the crinoid column. Lethaia 23, 291-296.

Grimmer, J.C., Holland, N.D. \& Hayami, I. 1985: Fine structure of the stalk of an isocrinid sea lily (Metacrinus rotundus) Echinodermata, Crinoidea). Zoomorphology 105, 39-50.

Grimmer, J.C., Holland, N.D. \& Kubota, H. 1984a: The fine structure of the stalk of the pentacrinoid larva of a feather star, Comanthus japonica (Echinodermata: Crinoidea). Acta Zoologica Stockholm 65, 41-58.

Grimmer, J.C., Holland, N.D. \& Messing, C.G. 1984b: Fine structure of the stalk of the bourgueticrinid sea lily Democrinus conifer (Echinodermata: Crinoidea). Marine Biology 81, 163-176.

Guensburg, T.E. 1992: Paleoecology of hardground encrusting and commensal crinoids, Middle Ordovician, Tennessee. Journal of Paleontology 66, 129-147.

Lane, N.G. 1963: The Berkeley crinoid collection from Crawfordsville, Indiana. Journal of Paleontology 37, 1001- 1008.

Lane, N.G. 1973: Paleontology and paleoecology of the Crawfordsville fossil site (Upper Osagian: Indiana). University of California Publications in Geological Sciences 99. $147 \mathrm{pp}$.

Macurda, D.B., Jr. \& Meyer, D.L. 1975: The microstructure of the cri noid endoskeleton. The University of Kansas Paleontological Contributions Paper 74. 22 pp.

Maples, C.G. \& Waters, J.A. 1995: Camptocrinus alabamensis (Mississippian: Chesterian) northern Alabama: A triple-folded, current-seeking, selective rheophilic camerate crinoid. Joumal of Paleontology 69, 367-375.

Moore, R.C., Jeffords, R.M. \& Miller, R.H. 1968: Morphological features of crinoid columnals. The University of Kansas Paleontological Contributions Echinodermata Article 8, 30 pp.

Moore, R.C. \& Teichert, C. (eds.) 1978: Treatise on Invertebrate Paleontology, Part $T$, Echinodermata 2:2. 1027 pp. Geological Society of America and University of Kansas Press, Lawrence, Kansas.

Morgan, J. \& Cannell, M.G.R. 1987: Structural analysis of tree trunks and branches: tapered cantilever beams subject to large deflections under complex loading. Tree Physiology 3, 365-374.

Riddle, S.W. 1989: Functional morphology and paleoecological implications of the platycrinitid column (Echinodermata, Crinoidea). Journal of Paleontology 63, 889-897. 
Riddle, S.W., Wulff, J.I. \& Ausich, W.I. 1988: Biomechanics and stereomic microstructure of the Gilbertsocrinus tuberosus column. In Burke R.1)., Mladenov, P.V., Lambert, P. \& Parsley R.L. (eds.): Echinodern Biology, 641-648. Balkema, Rotterdam.

Springer, F. 1926: Unusual forms of fossil crinoids. U.S. National Museum Proceedings 67:9.137 pp.

Stukalina, G.A. 1988: Studies in Paleozoic crinoid columnals and stems. Palaeontographica 24, 1-66.

Van Sant, J.F. \& Lane, N.G. 1964: Crawfordsville (Indiana) crinoid studies. University of Kansas Paleontological Contributions Article 7. $136 \mathrm{pp}$.

Ubaghs, G. 1978: Skeletal morphology of fossil crinoids. In Moore, R.C. \& Teichert, C. (eds.): Treatise on Invertebrate Paleontology, Part T,
Echinodermata 2:2, T58-T216. Geological Society of America and University of Kansas Press, Lawrence, Kansas.

Wachsmuth, C. \& Springer, F. 1897: The North American Crinoidea Camerata. Harvard College Museum of Comparative Zoology Memoir 20. 21, $897 \mathrm{pp}$.

Wilkie, I.C. \& Emson, R.H. 1988: Mutable collagenous tissues and their significance for echinoderm palaeontology and phylogeny. In Paul, C.R.C. \& Smith, A.B. (eds.): Echinoderm Phylogeny and Evolutionary Biology, 311-330. Clarendon, Oxford.

Wilkie, I.C., Emson, R.H. \& Young, C.M. 1993: Smart collagen in sea lilies. Nature 366, 519-520.

Wulff, J.I. \& Ausich, W.I. 1989. Growth of the xenomorphic crinoid column (Taxocrinus, Late Mississippian). Journal of Paleontology 63, $657-662$.

\title{
Erratum
}

The following note was inadvertently published without its accompanying illustration in Lethaia, Vol. 28, pp. 137-138 (1995). For ease of reference, the full text is reprinted here with the illustration.

\section{Generalized graptolite zonal sequence defining Silurian time intervals for global paleogeographic studies}

\author{
TATYANA N. KOREN, ALFRED C. LENZ, DAVID K. LOYDELL, MICHAEL J. MELCHIN, PETR STORCH AND \\ LECH TELLER
}

In connection with the ongoing correlation and paleogeography project sponsored by the Subcommission on Silurian Stratigraphy (SSS), an agreement has been reached on a generalized graptolite zonation (GGZ) for a left-hand biostratigraphic column (LBC), which first and foremost is meant to be used as a bridge in the construction of paleogeographic correlation maps for the 1996 James Hall Meeting (see Johnson 1993).

During recent decades, different versions of the graptolite $L B C$ have been used for the recognition of the Silurian series and stages. These schemes were usually combinations of the most complete regional sequences studied in the British Isles, Bohemia and Poland (Koren \& Kalio 1976; Rickards 1989; Jaeger 1991; Teller 1964; Urbanek 1970). There has never existed, however, a standard graptolite sequence or general agreement about the principles of graptolite zonation. In the detailed zonal charts referenced above, we find a mixture of range and assemblage zones of different kinds, sometimes with inadequately defined boundaries. In practical usage, it appears that graptolite zones are not well established for some time intervals and some established zones are not traceable worldwide. Sometimes, the same index species has been used to define different time intervals. In order to remedy these difficulties an attempt has been made to construct a more general graptolite zonation to serve as the $\mathrm{LBC}$ for global correlation charts, based on the same classical sequences. Already in some cases within the standard zonation' of Koren (1984), two or three regional zones were combined into larger, but more easily correlatable units. Since the Tallinn meeting of the SSS in 1990, this zonation has been emended and discussed with regard to the possible global extent of zones, their labelling, and likely duration.

The prototype model for a GGZ was considered at the Prague meeting of the SSS in 1992 and subsequently circulated in the 1993 issue (pp.
6-8) of Silurian Times (newsletter of the Silurian Subcommission, ICS, IUGS). Later on, a slightly modified version of this chart was widely discussed by graptolite and non-graptolite members of the SSS, both orally and by written communication (Silurian Times 1994, pp.6-10). Most of the published and unpublished comments and opinions were incorporated into a revised version of the chart, prepared by one of us (Koren 1994) for presentation at the 1994 meeting of the SSS in the Carnic Alps of Austria. With a rapidly approaching deadline for the completion of assignments for the James Hall Meeting, final modifications to the chart were entertained during this field meeting. The authors participated in several evening discussions, in which each zonal unit was considered separately in stratigraphic order with respect to its boundary definition, characterization, labelling and global traceability. The decision on incorporation of each unit into the GGZ was settled by majority vote.

The resulting GGZ (Fig. 1) is based on the combined species range data established in the most complete sequences of the British Isles, Bohemia, Poland, South Tien Shan, China, and Canada. A unified approach was taken, in most cases, to define zonal boundaries by the first appearance (FA) of index species. Many well traceable regional subdivisions represented by a single zone (e.g., the convolutus, sedgwickii, lundgreni and ludensis zones) are included in the GGZ. By definition of their boundaries, they are total or partial range zones, which implies that the upper limit of each zone is defined by the base of the next zone established by the FA of the next index species. All zones are characterized by certain diagnostic assemblages. For their labelling, it was agreed to use one well-known and widely distributed index species instead of two, as had been suggested earlier (e.g., nilssoni and formosus as opposed to nilssoni/colonus and formosus/spineus zones). Several zones were relabelled with an advantage to better traceability, taking into consideration 